\title{
Shocking Labor Supply: A Reassessment of the Role of World War II on Women's Labor Supply
}

\section{Citation}

Goldin, Claudia, and Claudia Olivetti. 2013. “Shocking Labor Supply: A Reassessment of the Role of World War II on Women's Labor Supply." American Economic Review 103, no. 3: 257-262.

\section{Published Version}

doi:10.1257/aer.103.3.257

\section{Permanent link}

http://nrs.harvard.edu/urn-3:HUL.InstRepos:13041327

\section{Terms of Use}

This article was downloaded from Harvard University's DASH repository, and is made available under the terms and conditions applicable to Other Posted Material, as set forth at http:// nrs.harvard.edu/urn-3:HUL.InstRepos:dash.current.terms-of-use\#LAA

\section{Share Your Story}

The Harvard community has made this article openly available.

Please share how this access benefits you. Submit a story.

Accessibility 


\title{
Shocking Labor Supply: A Reassessment of the Role of World War II on Women's Labor Supply
}

\author{
By Claudia Goldin and Claudia Olivetti*
}

The dominant feature of the female labor force in the United States across the twentieth century is its striking and large increase. But continuity in the increase may be an illusion. Women's paid employment may have been permanently altered by certain events.

The 1940s have been viewed as such a watershed decade. Labor force changes from 1940 to 1945 were huge. Around 14 million men were mobilized, the male labor force declined by almost 9 million, and the female labor force, which stood at 14 million in 1940, increased by more than 7 million. ${ }^{1}$ Surveys show that various norms loosened during the 1940s. But according to a revisionist view the changes did not persist. Women were forced off their jobs at war's end, and the war propaganda machine went into reverse gear after VJ-Day, extolling the virtues of women's role in the home. ${ }^{2}$

Longitudinal data have been used to determine the veracity of these two opposing views. Various surveys, including the originals underlying the Palmer report, enabled a piecing together of cohort work histories (Goldin 1991a). Among the many findings is that the women who entered

* Goldin: Department of Economics, Harvard University, Cambridge, MA 02138 (e-mail: cgoldin@harvard.edu); Olivetti: Department of Economics, Boston University, Boston, MA 02115 (e-mail olivetti@bu.edu). We thank Larry Katz for comments. Shuheng Lin and Chenzi Xu provided extraordinary research assistance.

${ }^{\dagger}$ To view additional materials and author disclosure statement $(\mathrm{s})$, visit the article page at http://dx.doi.org/10.1257/aer.103.3.257.

${ }^{1}$ During the war, 11.5 million men 18 to 44 years old were drafted or enlisted at their draft board and 3.1 million volunteered, but not all were eligible to serve. Male employment fell by only 3.5 million because the unemployment rate was still high in 1940. The decrease for men is from the peak in July 1940 to the trough in January 1945; the increase for women is from the trough in January 1941 to the peak in July 1944. US Bureau of the Census (1947), Tables 4 and 5.

${ }^{2}$ Goldin (1991a) contains a bibliography of the "watershed" and "revisionist" literatures. the work force during the World War II years accounted for just 20 percent of the married women 27 to 51 years old who were employed in 1951. From this evidence WWII did not look like a great watershed in the employment of women. Yet, WWII could still have had an effect to 1950 , and its longer-run impact could have been greater still. But the longitudinal data used ended in 1951.

The war's impact on female labor force participation to 1945 does not appear to have resulted from increases in real, after-tax wages. Pretax real wages did rise, but after-tax wages actually fell because of the large tax hikes. ${ }^{3}$ Because female employment during the war soared, a usual explanation that relies on an increased opportunity cost of time would not seem to be correct.

Standard models of changing household budget sets may not be fully applicable to the early 1940s because of the end of employment restrictions in the form of "marriage bars" (Goldin 1991b) and because unemployment in 1940 was 15 percent. Employment could have soared even though real, after-tax wages were stable. But another factor may have operated. Employment may have increased substantially for women because their labor supply function shifted to the right.

That possibility is supported by a recent finding about the impact of the war on women's employment by Acemoglu, Autor, and Lyle (2004) — henceforth, AAL — in a paper that cleverly uses state mobilization rates to identify the impact of the war. ${ }^{4}$ The mobilization rate is the fraction of males between certain ages who were

\footnotetext{
${ }^{3}$ According to Mulligan (1998, Table 1) real after-tax wages for women fell by 4 percent from 1940 to 1944 and then rose by 17 percent from 1944 to 1948 .

${ }^{4}$ Other researchers have used this identification, including Fernández, Fogli, and Olivetti (2004), who find a long-
} 
inducted into the military. It varied geographically for many reasons exogenous to initial levels of female employment and provides a way to measure the "treatment effect" of the war. The goal of AAL, however, was to assess the impact of female labor supply on the wage structure, not to estimate the role of the war on women's labor supply.

Our purpose is to identify the short- and longrun impacts of WWII on women's labor supply by using the mobilization rates for various types of men. We term these effects as "shocking" labor supply, and we divide the factors affecting labor supply into those that were general and those that were specific. We concentrate on women who were young during the war years ( 25 to 34 years old in 1950 and 35 to 44 years old in 1960) and currently married in 1950 or 1960 since they would have been more constrained by social norms before the war and potentially more "treated" by the war.

The general influence of the war would have affected all women living through the period. The specific influence of the war would have been experienced by women whose husbands were in the armed services. Their labor supply would have shifted to the right due to an income effect, since their husbands earned less than in their civilian jobs, and also because husbands were often an impediment to a wife's working for pay. Women whose husbands were away during the war years had twice the employment rate in 1944 of those in the same age group whose husbands were not away (see Goldin 1991a, Table 1).

We find that most of the impact was general in nature and that the aggregate mobilization rate produces the largest and most robust effect on weeks worked and labor force participation. The impact, moreover, was experienced almost entirely by women in the top half of the education distribution. We uncover effects for 1950, which we term the short-run impact, and for 1960, a longer-run effect. Women who were married but without children during WWII were most impacted by the mobilization rate in 1950 . By 1960 WWII still influenced their labor supply decisions and also those of women with children during WWII.

run effect on women's labor supply operating through the marriage market.

\section{Identifying the "Shocking" of Female Labor Supply by WWII}

\section{A. World War II Mobilization Rates}

Mobilization in the United States began September 16, 1940 with the Selective Training and Service Act, which called for the registration of all men 21 to 35 years old. Deferments could be granted based on dependents, occupation, and fitness to serve. Registration was extended five additional times. Wives were initially considered dependents, as were children if born before September 15, 1942. The wife deferment ended April 12, 1943, and the automatic child deferment ended December 11, 1943, although mobilization rates for fathers were low, and they were generally drafted only after others in the local draft board pool were exhausted. Certain agriculture and war-industry occupations were deferments and some men, deemed IV-F, were exempt because of physical and mental disabilities. On April 21, 1944, however, almost all deferments were eliminated. 5

To identify the general and specific treatment effects of WWII on women, we have produced mobilization rates from US Selective Service bulletins for several groups of men by race, age, and parental status as of August 1, 1945 (see Goldin and Olivetti 2013, Table A.1). We present here only the results using the aggregate rate for all 18-to-44-year-olds, termed $M O B$, which is almost identical to that used by AAL. ${ }^{6}$ The total mean is 0.462 , and it varies by state from 0.400 to $0.536 .{ }^{\top}$

Our estimation relies on the fact that mobilization rates varied by state because of the factors that led to deferments (see Acemoglu, Autor, and Lyle 2004, Table 4, and Goldin and Olivetti 2013, Table A.2). Quotas were set from the number of registrants available for service (I-A) plus those already serving (I-C). Thus, the higher the number of deferments, the lower would be the mobilization rate since registrants included those with deferments.

\footnotetext{
${ }^{5}$ See also Acemoglu, Autor, and Lyle (2004) on WWII mobilization and US Selective Service (various years).

${ }^{6}$ The main difference is that they use inductions as of January 1946 .

${ }^{7}$ Goldin and Olivetti (2013) discuss alternative mobilization rates. Here we make reference to results that use a mobilization rate for white men 18 to 37 years old.
} 


\section{B. Identification Strategy}

The idea behind our identification strategy is that various groups of (white) women who went through the war may have been treated differently by the mobilization of men. All were affected by the increase in demand for their own labor in local labor markets (here US states) and by a desire to aid the nation in its war effort. Those who were married at the time of increased mobilization were affected by the induction of their husbands, including the reduction in their family income and their increased independence. Those who had children would have been less impacted by the mobilization of their husbands because the induction rate for fathers was far less than for nonfathers, and women with children had low labor force participation rates.

We have two main samples of white (nonfarm) married women. Those who were 25 to 34 years old in 1950 and those 35 to 44 years old in 1960. Women in both samples were 16 to 29 years old in 1941 to 1945 , the years of US involvement in WWII. These women went through the war years in one of three demographic circumstances: married with children; married without children; and unmarried. In each case the control group includes comparable women in 1940 similarly situated demographically during a "pseudo" WWII period in the 1930s. 8

We consider two outcomes: weeks worked and labor force participation. We use the 1940, 1950, and 1960 Integrated Public Use Microdata Series (IPUMS) of the US population census (Ruggles et al. 2010). The mobilization rates are given by state of birth to ensure greater exogeneity. We first investigate if there was a treatment effect of WWII over the short run to 1950 and then if the treatment had a longer-run or more lasting effect on female labor supply to 1960 .

The general version of the estimating equation is

$$
\begin{aligned}
y_{i t s}= & \varphi_{s}+\gamma d_{\tau}+\alpha_{t} Z_{i t} \\
& +\beta_{t} d_{\tau} X_{s 1940}+\delta d_{\tau} M O B_{s}+\varepsilon_{i t s}
\end{aligned}
$$

\footnotetext{
${ }^{8}$ For selection rules, see notes to Table 1. Goldin and Olivetti (2013) has further details on the data and empirical strategy. We use white women because black women's participation was high before the war and many were in agricultural occupations, excluded here.
}

where $y_{i t s}$ is an outcome, either weeks worked or labor force participation, for person $i$ in year $t$ and having state of birth $s . \varphi_{s}$ are state of birth dummies, $d_{\tau}$ is a year dummy for either $\tau=1950$ or 1960, and $Z_{i t}$ are covariates for woman $i$ such as number of children and age dummies. $X_{s 1940}$ are state of birth covariates such as fraction of male employment in farm occupations, fraction black, and mean level of education of the adult population all as of 1940. These covariates, identified by AAL, are included to account for differences in mobilization by state that may be correlated with the outcome variables. The coefficient of greatest interest is $\delta$, that on the interaction of the year dummy and the relevant mobilization rate $\left(M O B_{s}\right)$ in the individual's state of birth.

When we use the three demographic groups (married with children, married without children, or single), we add main effects, an interaction with the year dummy, and another with the mobilization rate and the year dummy. It is this triple difference on which we will focus. Furthermore, we divide the samples roughly in half by those who have graduated from high school and those who have not, and we estimate the equation for each group separately.

Weeks of work and labor force participation rates for our samples do not vary consistently by mobilization rates in the state of birth for 1940 (see Goldin and Olivetti 2013, Table A.3). Thus, the use of the mobilization rate is a valid empirical strategy.

\section{Results and Interpretation}

Women who were 25 to 34 in 1950 appear to have been impacted by WWII, as can be seen from the coefficients on the triple differences in columns 1 and 2 of Table 1. Married women 35 to 44 years old in 1960 also experienced a substantial increase in both weeks worked and labor force participation relative to their demographic counterparts in 1940 (see columns 3 and 4). We have not included the estimation for the less-educated women in Table 1 since, for both age groups, those coefficients have fairly large standard errors and are occasionally of the wrong sign (Goldin and Olivetti 2013, Tables 3 and 4). But the estimates for the more-educated women are positive, large and more precisely estimated for both outcomes. The finding that the more-educated group was impacted, whereas the less-educated group 
Table 1-Impact of World War II Mobilization on the Labor Supply of More-Educated White, Married Women

\begin{tabular}{|c|c|c|c|c|}
\hline & \multicolumn{2}{|c|}{$25-34$ years old in 1950} & \multicolumn{2}{|c|}{$35-44$ years old in 1960} \\
\hline & $\begin{array}{c}\text { Weeks worked } \\
\text { (1) }\end{array}$ & $\begin{array}{c}\text { LFPR } \\
(2)\end{array}$ & $\begin{array}{c}\text { Weeks worked } \\
\text { (3) }\end{array}$ & $\begin{array}{c}\text { LFPR } \\
(4)\end{array}$ \\
\hline$\tau \times M O B \times$ MarrChildWWII & $\begin{array}{c}23.65 \\
(15.48)\end{array}$ & $\begin{array}{l}0.90 * * * \\
(0.3)\end{array}$ & $\begin{array}{l}42.68 * * \\
(17.86)\end{array}$ & $\begin{array}{c}0.68 * \\
(0.41)\end{array}$ \\
\hline$\tau \times M O B \times$ MarrNoChildWWII & $\begin{array}{l}43.33 * * \\
(17.14)\end{array}$ & $\begin{array}{l}0.96 * * * \\
(0.34)\end{array}$ & $\begin{array}{l}31.89 * * * \\
(12.06)\end{array}$ & $\begin{array}{l}0.64 * * \\
(0.31)\end{array}$ \\
\hline$\tau \times M O B \times$ UnmarrWWII & $\begin{array}{c}37.95 * \\
(19.48)\end{array}$ & $\begin{array}{c}0.79 \\
(0.49)\end{array}$ & $\begin{array}{c}7.61 \\
(15.11)\end{array}$ & $\begin{array}{l}0.1 \\
(0.35)\end{array}$ \\
\hline Constant & $\begin{array}{l}18.15^{* * * *} \\
(0.88)\end{array}$ & $\begin{array}{l}0.39 * * * \\
(0.02)\end{array}$ & $\begin{array}{l}13.19 * * * \\
(1.01)\end{array}$ & $\begin{array}{l}0.30 * * * \\
(0.02)\end{array}$ \\
\hline $\begin{array}{l}\text { Observations } \\
R^{2}\end{array}$ & $\begin{array}{c}20,846 \\
0.16\end{array}$ & $\begin{array}{c}20,846 \\
0.14\end{array}$ & $\begin{array}{c}49,009 \\
0.11\end{array}$ & $\begin{array}{c}49,009 \\
0.11\end{array}$ \\
\hline
\end{tabular}

Notes: $\tau=1950$ (columns 1, 2) or 1960 (columns 3, 4). Standard errors are clustered at state of birth and year level. Our sample includes white, married women with $\geq 12$ years of school, in their first marriage, not in institutional group quarters, not employed in farming, and born in and residing in the continental United States excluding the District of Columbia and Nevada. We use sample line weights. Women with children during WWII are those living with an eldest child at least five years old in 1950 (15 in 1960). MOB is the mobilization rate for all men 18 to 44 years old in the woman's state of birth. MarrChildWWII $=$ married with children during WWII or the pseudo-WWII period in the 1930s; MarrNoChildWWII = married without children during the WWII or pseudo-WWII period; UnmarrWWII = not married during the WWII or pseudo-WWII period. Regressions include main effects for the three groups, and their interaction with $\tau$ and $M O B, 1940$ state of birth covariates interacted with $\tau$. Individual covariates are state of birth and age dummies, number of children $<5$ years and number of children $\geq 5$ years.

*** Significant at the 1 percent level.

** Significant at the 5 percent level.

* Significant at the 10 percent level.

Source: 1940, 1950, and 1960 IPUMS of the US decennial population censuses (Ruggles et al. 2010).

was generally not, is a robust result and found in virtually all of our estimations.

In interpreting the Table 1 results we will compare states with low mobilization rates to those with high mobilization rates. We use a simple difference metric: the mobilization rate of the median state in the "high" group minus that of the median state in the "low" group. The measure is equivalent to the difference between the rate of the eighth highest and the eighth lowest states by mobilization rate. For the aggregate mobilization rate the state difference metric is 6.8 percentage points.

Consider, first, the results on weeks worked for the 25-to-34-year-old women in 1950. For those who were married and without children, the effect of a change in the mobilization rate of 6.8 percentage points is 2.9 weeks $(=43.33 \times 0.068)$, or about a 28 percent increase compared with the 1940 or 1950 mean for the group (around 10 or 11 weeks) $[9$ The change for women who were

\footnotetext{
${ }^{9}$ The means for weeks worked and the labor force participation rate are in Goldin and Olivetti (2013), Table 2.
}

not married during WWII is 2.6 weeks $(=37.95$ $\times 0.068$ ) or about an 18 percent increase from the 1940 mean for the group of 14 weeks.

The coefficient is smaller (and less precisely estimated) for women who were married with children during the war. These women would have had less ability to be impacted directly by the increased demand for their labor than women in the other groups. In contrast, those who were already married during the war but had no children would have had the double impact of having an increased demand for their labor and husbands who were most likely away in the armed forces. That interpretation seems to be borne out when we use the aggregate mobilization rate, as in Table 1 , and also when we use the mobilization rate for white men 18 to 37 years old (see Goldin and Olivetti 2013, Table A.4).

We find similar results for the labor force participation rate, but with a few differences. For women without children, the impact of changing the mobilization rate by 0.068 is 0.065 $(=0.96 \times 0.068)$ or about a 30 percent increase using either the 1940 or 1950 participation rate 
(about 0.22). The impact is a bit smaller for married women with children, but participation rates for that group are lower so the effect as a fraction of the participation rate is larger. The coefficient for women who were not married during WWII is smaller and less significant than for the others. ${ }^{10}$

Finally, and perhaps most important, are the results for women 35 to 44 years old in 1940 and 1960 (columns 3 and 4). In this case women who were married during WWII with or without children show the greatest longer-run impact from changes in the mobilization rate.

For the magnitude of the effect, we again use the difference metric. For married women with children, the coefficient in Table 1 implies an increase of 2.9 weeks $(=42.7 \times 0.068)$ or about 24 percent of the 1940 and 1960 average of about 12 weeks. The estimate for married women without children is a bit lower and results in an increase of 2.2 weeks or 20 percent of the 1940 and 1960 average.

Similarly, the coefficient for the labor force participation of women with children during WWII implies a change of 4.6 percentage points $(=0.68 \times 0.068)$ or 17 percent of the 1940 to 1960 mean of 0.28 for the group. The impact for the married women without children is about the same.

In summary, the impact of WWII as indicated by the relationship between labor supply outcomes and the mobilization rate is found for both weeks worked and labor force participation. In all cases, it is experienced almost entirely by those who were more educated. The impact is generally stronger in 1950 for white women who did not have children during WWII, and it is similarly strong by 1960 for those who were married during WWII, with or without children. We also find effects of a similar order of magnitude for married women 35 to 49 years old in 1950 but not for women who were older. Our findings are robust to assigning mobilization rates by state of residence. Excluding Southern states made the short-run results somewhat larger, although those for 1940 to 1960 were less robust. We do not find that states with higher mobilization rates had a very different

\footnotetext{
${ }^{10}$ However, all three groups show a statistically significant response to changes in the mobilization rate of white men 18 to 37 years old (see Goldin and Olivetti 2013, Table A.4).
}

fraction of their female labor forces employed in office, retail sales, managerial, and professional occupations in 1940 relative to those with low mobilization rates. ${ }^{11}$

\section{Concluding Remarks on Shocking Female Labor Supply}

Did WWII have a "shocking" effect on women's labor supply as the "watershed theory" posits, or did it have no persistent impact as the "revisionists" would assert? Our work allows an integration of the two views of WWII and women's labor supply.

By identifying the impact of WWII using the mobilization rate instrument we find that states with higher mobilization rates did experience an increase in female labor supply measured in terms of weeks worked and labor force participation. The impact is perceptible only among the upper half of women by level of schooling. In addition, the shorter-run impact of WWII was greatest among those who did not have children during WWII, whereas the longer-run impact was greatest for those with children during WWII. In almost all cases the impact of mobilization on weeks and participation for the higher-educated group was substantial, around 20 percent of the average level for the period considered.

How do these findings bear on the question posed? To better interpret our findings we use the Palmer survey that retrospectively followed women's work histories from 1940 to 1951. Women 25 to 44 years old in 1951 who entered the work force from 1940 to 1944 were probably "shocked" by the increased demand for female labor during WWII. But which of these women had a persistent effect of the "shock"?

The Palmer survey allows us to observe the occupations of these women and their education. Of great importance is that the occupations these women had in 1944 greatly depended on their level of education. Among those with at least a high school diploma, almost 80 percent were in white-collar jobs. But for those with less than a high school diploma just 25 percent were in white-collar positions. About 75 percent were in blue-collar jobs, and the vast majority

\footnotetext{
${ }^{11}$ Goldin and Olivetti (2013) contains further robustness checks.
} 
of these were in manufacturing. By 1950 these women's occupations were not much different than in 1944, except that manufacturing positions decreased and service occupations took their place among the lesser-educated group.

Although the survey does not allow us to trace women who entered the labor force in 1944 but did not continue to 1951 , it provides clues to why the higher-educated women would have had a persistent impact from the "shock." Lowereducated women were disproportionately pulled into manufacturing positions to 1944 , and many probably did not remain because women were often unwelcome in them. The more-educated group, however, entered sectors that enabled women to remain to 1950 and beyond.

Our work helps reconcile the watershed and revisionist views of WWII. Women's labor supply was altered by the war. Women whose labor supply was shifted appear to have been those who entered white-collar positions from 1940 to 1944. For some of them, WWII involved a "shock" to their labor supply that had persistent effects.

\section{REFERENCES}

Acemoglu, Daron, David H. Autor, and David Lyle. 2004. "Women, War, and Wages: The Effect of Female Labor Supply on the Wage Structure at Midcentury." Journal of Political Economy 112 (3): 497-551.

-Fernández, Raquel, Alessandra Fogli, and Claudia Olivetti. 2004. "Mothers and Sons: Preference Formation and Female Labor Force Dynamics." Quarterly Journal of Economics 119 (4): 1249-99.
Goldin, Claudia D. 1991a. "The Role of World War II in the Rise of Women's Employment." American Economic Review 81 (4): 741-56.

Goldin, Claudia D. 1991b. "Marriage Bars: Discrimination against Married Women Workers from the 1920s to the 1950s." In Favorites of Fortune: Technology, Growth, and Economic Development since the Industrial Revolution, edited by H. Rosovsky, D. Landes, and P. Higonnet, 511-36. Cambridge, MA: Harvard University Press.

Goldin, Claudia, and Claudia Olivetti. 2013. "Shocking Labor Supply: A Reassessment of the Role of World War II on Women's Labor Supply." National Bureau of Economic Research Working Paper 18676.

-Mulligan, Casey B. 1998. "Pecuniary Incentives to Work in the United States during World War II." Journal of Political Economy 106 (5): 1033-77.

Ruggles, Steven, J. Trent Alexander, Katie Genadek, Ronald Goeken, Matthew B. Schroeder, and Matthew Sobek. 2010. Integrated Public Use Microdata Series: Version 5.0 [Machine-readable database]. Minneapolis: University of Minnesota.

US Census Bureau, Department of Commerce. 1947. Labor Force, Employment, and Unemployment in the United States, 1940 to 1946. Current Population Reports, Labor Force Bulletin, Series P-50, No. 2. Washington, DC: US Department of Commerce.

US Selective Service System. 1946, 1947, 1948, 1950. Special Monographs 5, Vol. III; 8; 9; 12 Vol. 1; 12 Vol. 2. Washington, DC: Government Printing Office. 